\title{
Protective Netting Improves Leaf-level Photosynthetic Light Use Efficiency in 'Honeycrisp' Apple Under Heat Stress
}

Giverson Mupambi ${ }^{1}$, Stefano Musacchi, Sara Serra, and Lee A. Kalcsits ${ }^{1}$ Department of Horticulture, Washington State University, Tree Fruit Research and Extension Center, $1100 \mathrm{~N}$ Western Avenue, Wenatchee, WA 98801

\author{
Desmond R. Layne \\ Department of Horticulture, Washington State University, P.O. Box 646414, \\ Pullman, WA 99164
}

\section{Tory Schmidt}

Washington Tree Fruit Research Commission, 1719 Springwater Avenue, Wenatchee, WA 98801

Additional index words. shade net, anti-hail net, apple production, fruit sunburn, dynamic photoinhibition, potted trees

\begin{abstract}
Globally, apple production often occurs in semiarid climates characterized by high summer temperatures and solar radiation. Heat stress events occur regularly during the growing season in these regions. For example, in the semiarid eastern half of Washington State, historic weather data show that, on average, $33 \%$ of the days during the growing season exceed $30{ }^{\circ} \mathrm{C}$. To mediate some of the effects of heat stress, protective netting $(P N)$ can be used to reduce the occurrence of fruit sunburn. However, the impacts of reduced solar radiation in a high light environment on light-use efficiency and photosynthesis are poorly understood. We sought to understand the ecophysiological response of apple (Malus domestica Borkh. cv. Honeycrisp) under blue photoselective PN during days with low $\left(26.6^{\circ} \mathrm{C}\right)$, moderate $\left(33.7^{\circ} \mathrm{C}\right)$, or high $\left(38.1^{\circ} \mathrm{C}\right)$ ambient temperatures. Two treatments were evaluated; an uncovered control and blue photoselective PN. Maximum photochemical efficiency of PSII, or photosystem II $\left(F_{v} / F_{m}\right)$ was significantly greater at all measurement times under blue photoselective PN compared with the control on days with high ambient temperatures. $F_{v} / F_{m}$ dropped below 0.79 , which is considered the threshold for stress, at $1000 \mathrm{HR}$ in the control and at $1200 \mathrm{HR}$ under blue photoselective PN on a day with high ambient temperature. On days with low or moderate ambient temperatures, $F_{v} / F_{m}$ was significantly greater under blue photoselective $P N$ at $1400 \mathrm{HR}$, which coincided with the peak in solar radiation. 'Honeycrisp' apple exhibited dynamic photoinhibition as shown by the diurnal decline in $F_{v} / F_{m}$. Quantum photosynthetic yield of PSII (ФPSII) was also generally greater under blue photoselective PN compared with the control for days with moderate or high ambient temperatures. Photochemical reflectance index $(\triangle P R I)$, the difference in reflectance between a stressresponsive and nonstress-responsive wavelength, was greater under PN compared with the control on the day with high ambient temperatures, with no differences observed under low or moderate ambient temperatures. Leaf gas exchange did not show noticeable improvement under blue photoselective netting when compared with the control despite the improvement in leaf-level photosynthetic light use efficiency. In conclusion, $P N$ reduced incoming solar radiation, improved leaf-level photosynthetic light use efficiency, and reduced the symptoms of photoinhibition in a high-light, arid environment.
\end{abstract}

Many of the most productive apple-growing regions in the world are located in semiarid climates such as Washington State, South Africa, Israel, Chile, and Australia. Washington State is the primary apple-production area in the United States, with a climate characterized by high ambient temperatures and solar radiation during the growing season. Plant growth and development is dependent on temperature, with an optimum range that is species dependent (Bita and Gerats, 2013; Hatfield and Prueger, 2015). In apple, high ambient temperatures and high solar radiation cause the fruit surface to overheat, leading to the development of fruit sunburn (Racsko and Schrader, 2012; Wünsche et al., 2004). The use of PN for reducing incoming solar radiation and protection against sunburn is gaining in popularity in commercial apple orchards (Mupambi et al., 2018). PN (also called antihail nets or shade nets) initially was developed as a physical barrier against hail damage. PN can protect trees against bird damage, fruit bats, insects, strong winds, and sand storms (Arthurs et al., 2013; Shahak et al., 2004). The colors of early PN were primarily black and white. Since then, PN was modified by adding chromatic elements, giving rise to photoselective PN that can modify the light spectrum within the orchard canopy (Shahak et al., 2008). For this study, the term PN will be used in the general sense and photoselective PN where it was specified as such in previous studies.

The use of PN can change the orchard environment. Depending on the porosity and material used, PN can reduce the amount of photosynthetically active radiation $(P A R)$ reaching the underlying plants and modify the light quality in the ultraviolet, $P A R$, and near-infrared wavelengths (Castellano et al., 2008; Shahak et al., 2016). The effects of PN on air temperature have been inconsistent. Middleton and McWaters (2002) reported that perceived cooler ambient temperatures under PN are due to reduced radiant heat (from lower sunlight levels) rather than a change in ambient temperature. $\mathrm{PN}$ has been reported to reduce ambient temperature (Middleton and McWaters, 2002; Solomakhin and Blanke, 2010), but Arthurs et al. (2013) found that $50 \%$ red, blue, and pearl PN increased ambient temperature. Kalcsits et al. (2017) found no significant differences in ambient temperature under photoselective PN compared with an uncovered control. The inconsistent results obtained may be due to radiation shielding not being used with the temperature sensors in some studies. For example, ambient temperature readings from a sensor that is exposed to solar radiation have been reported to be 4 to $6{ }^{\circ} \mathrm{C}$ higher than ambient temperature readings from inside a Stevenson Screen (Middleton and McWaters, 2002). Photoselective PN reduced soil temperature under Washington State conditions at depths of 20 and $40 \mathrm{~cm}$ (Kalcsits et al., 2017). PN also has been reported to lower the wind speed (Arthurs et al., 2013; Kalcsits et al., 2017; Middleton and McWaters 2002) and increase relative humidity (Middleton and McWaters, 2002; Solomakhin and Blanke, 2010).

Heat damage from excessively high leaf temperatures affects photosynthetic reactions, posing limitations for growth and survival of plants (Berry and Bjorkman, 1980; Seemann et al., 1984). Heat stress can cause morphological, physiological, and biochemical changes that reduce photosynthetic efficiency, plant growth, and productivity (Ashraf and Harris, 2013). Leaves exposed to full sunlight can heat up substantially above ambient temperature (Sharkey, 2005). The leaf temperature of 'Honeycrisp' apple was reported to be $36.2{ }^{\circ} \mathrm{C}$ when ambient temperature was $28.8{ }^{\circ} \mathrm{C}$ (Kalcsits et al., 2017). Enzymes involved in chlorophyll biosynthesis are affected by heat stress (Tewari and Tripathy, 1998). Heat stress deactivates RuBisCo, an enzyme involved in the first major step of carbon dioxide fixation (Salvucci and Crafts-Brandner, 2004). With increasing heat stress, the ratio of photorespiration to photosynthesis increases (Sharkey, 2005). Inactivation of PSII was observed above $38{ }^{\circ} \mathrm{C}$ in Solanum tuberosum L., together with damage to the thylakoid membrane (Havaux, 1996). Yan et al. (2011) reported that PSII performance in leaves of Sorghum 
bicolor L. was negatively affected by high temperature, with the acceptor side of PSII being more sensitive than the donor side and reaction center.

Saturation of the leaf photosynthetic apparatus occurs at high levels of solar radiation and results in a decrease in photosynthetic light use efficiency (Li and Yang, 2015). This process is referred to as photoinhibition and occurs when the rate of photodamage to PSII is greater than the rate of repair of photodamaged PSII (Murata et al., 2007). The measurement of photosynthetic light use efficiency can be used to estimate plant photosynthesis and net primary production (Flanagan et al., 2015; Liu et al., 2013). Leaf-level photosynthetic light use efficiency can be measured using leaf spectral reflectance and chlorophyll fluorescence. Leaf spectral reflectance can be used to obtain the photochemical reflectance index, which provides a measure of photosynthetic light use efficiency (Gamon et al., 1992). The most common chlorophyll fluorescence protocols used to measure the photosynthetic efficiency of PSII are $\mathrm{F}_{\mathrm{v}} / \mathrm{F}_{\mathrm{m}}$ and ФPSII (Maxwell and Johnson, 2000). Photosynthetic light use efficiency as measured by $\mathrm{F}_{\mathrm{v}} / \mathrm{F}_{\mathrm{m}}$ began to decline at temperatures above $37^{\circ} \mathrm{C}$ in Vitis californica (Gamon and Pearcy, 1989).

Modification of the orchard environment under PN results in changes in apple tree physiology. PN has been reported to improve water use efficiency in 'Cripps Pink' apple (Gindaba and Wand, 2007a) and reduce stem water potential in 'Smoothee Golden Delicious' (Shahak et al., 2004). The effect of $\mathrm{PN}$ on leaf photosynthesis has been variable. Leaf photosynthesis was increased in 'Cripps Pink', 'Royal Gala', and 'Fuji' (Bastías et al., 2012; Gindaba and Wand, 2007a, 2007b; Solomakhin and Blanke, 2008), reduced in 'Fuji' and 'Golden Delicious' (Ebert and Casierra, 2000; Solomakhin and Blanke, 2008), and unaffected in 'Starkrimson' and 'Fuji' (Romo-Chacon et al., 2007; Solomakhin and Blanke, 2008). Photosynthesis in fieldgrown apples has been shown to decline above the ambient temperature of $30{ }^{\circ} \mathrm{C}$ (Gindaba and Wand, 2007b; Pretorius and Wand 2003). In growing regions like Washington State, ambient temperatures regularly exceed this threshold during the growing season. In addition, under climate change in the future, heat stress events are more likely to occur during the growing season (Teixeira et al., 2013). Here, the primary objective was to

\footnotetext{
Received for publication 23 Mar. 2018. Accepted for publication 30 July 2018 .

We thank Katie Mullin, Jordan Briggs, Michelle Reid, and Chelsea Hill from the Kalcsits Lab at the WSU Tree Fruit Research and Extension Center for assistance with data collection. Funding for the research was provided by the Washington State Department of Agriculture Specialty Crop Block Grant (K1771) and the Washington Tree Fruit Research Commission (AP-15-104A). The contribution of anonymous reviewers who greatly improved the quality of this manuscript is acknowledged.

${ }^{1}$ Corresponding authors. E-mail: lee.kalcsits@wsu. edu or giverson.mupambi@wsu.edu.
}

determine whether the reduction in excessive solar radiation under blue photoselective PN at different ambient temperature conditions impacts leaf-level photosynthetic light use efficiency, leaf gas exchange, leaf spectral reflectance, and plant water status in a semiarid climate.

\section{Materials and Methods}

Study site, plant material, and treatments

Experiments were conducted on potted 'Honeycrisp'/'M-9-T337' apple trees (Malus domestica Borkh.) at Washington State University Tree Fruit Research and Extension Center in Wenatchee, WA (lat. $47^{\circ} 26^{\prime} 29.1^{\prime \prime} \mathrm{N}$; long. $120^{\circ} 20^{\prime} 90.1^{\prime \prime} \mathrm{W}$ ). Trees were planted in 2015 in 30-L pots and the growing medium was Sunshine Mix \#2 (Sun Gro Horticulture, Agawam, MA). The potted trees were spaced at a spacing of $0.6 \times 1.5 \mathrm{~m}$. Trees were watered four times per day for $30 \mathrm{~min}$ each using drip irrigation at a rate of $3.78 \mathrm{~L}$ per hour. Trees were fertilized using Coastal 16-16-16 AllPurpose Fertilizer (Coastal Farm \& Ranch Supply, Albany, OR) comprising 16\% total nitrogen $(8.50 \%$ ammoniacal nitrogen and $7.50 \%$ urea nitrogen), $16 \%$ available phosphate $\left(\mathrm{P}_{2} \mathrm{O}_{5}\right), 16 \%$ soluble potash $\left(\mathrm{K}_{2} \mathrm{O}\right)$, and $6 \%$ sulfur. The fertilizer was applied monthly during the growing season, and seasonal checks on leaf elemental analysis did not reveal any deficiencies. Full bloom occurred on 13 Apr. 2016 and 4 May 2017. Crop load was thinned to a target crop load of 4 fruit $/ \mathrm{cm}^{2}$ TCSA when fruit was $10 \mathrm{~mm}$ in diameter. The average tree height at the time of the experiment in 2016 was $2.1 \mathrm{~m}$. The experiments were conducted on days when the ambient temperature was high (6 June 2016), moderate (30 June 2017), and low (2 June 2017).

Measurements were taken at 2-h intervals from 0800 to $1600 \mathrm{HR}$ for each ecophysiological parameter measured. Two healthy fully expanded leaves per treatment replication were measured for each parameter and time point. Measurements were done on sun-exposed leaves from the outer canopy assumed to have reached photosynthetic steady state for at least $20 \mathrm{~min}$ and located between 1.5 and $2.0 \mathrm{~m}$ aboveground level. There were two treatments: an uncovered control plot with no netting and a shade house plot under blue photoselective PN (Blue ChromatiNet; Polysack Plastics Industries, Nir-Yitzhak, Israel). The shade house plot was a hoop house exclusion netting structure (top and all sides completely covered) and was $7.30 \mathrm{~m}$ long, $6.4 \mathrm{~m}$ wide, and $4.5 \mathrm{~m}$ high at the apex. The shade factor for the blue photoselective PN was $22 \%$, with mesh size $3 \times 5 \mathrm{~mm}$ and made from woven monofilament high-density polyethylene. There was a total of 44 trees in the netting structure, arranged in four rows of 11 tree each. The plots were located next to each other with boundary trees in between and were the same size. For blue photoselective PN-covered trees, the net was installed on 6 May 2016 and 16 May 2017. To minimize boundary effects, 10 trees in the middle of each plot were randomly selected and used for measurements. The trees in the experimental plots were under normal commercial cultural practices for young trees in terms of pruning, irrigation, pest management, and fertilization.

\section{Weather data}

Historical weather data for the site were collected from an automatic weather station located $120 \mathrm{~m}$ from the trial site (AgWeatherNet, 2017). The weather station was equipped with a temperature and relative humidity probe (HC2S3-L; Rotronic, Hauppauge, NY) and a 3-cup anemometer (014A-L; Met One, Grants Pass, OR). The temperature sensor and anemometer were located $1.5 \mathrm{~m}$ and $2.0 \mathrm{~m}$ above the ground, respectively. The logging interval for the automatic weather station was $15 \mathrm{~min}$. Microclimatic conditions for each treatment plot were measured using four relative humidity and temperature sensors (VP-4; Metergroup, Pullman, WA) housed in a radiation sensor (40021; Metergroup), a PAR quantum sensor (SQ-110; Apogee Instruments, Logan, UT) located $3 \mathrm{~m}$ above the orchard floor and four soil moisture, and temperature capacitance sensors inserted $0.2 \mathrm{~m}$ into the potting mixture (5TM; Decagon Devices Inc., Pullman, WA) were installed in each treatment plot. Each group of sensors was connected to two wireless cellular data loggers (Em50G; Decagon Devices Inc.) to remotely log and transmit data with a logging interval of $30 \mathrm{~min}$.

\section{Ecophysiological measurements}

Chlorophyll fluorescence and leaf spectral reflectance. Chlorophyll fluorescence was measured using a pulse modulated, chlorophyll fluorometer, (OS1p; Opti-Sciences, Hudson, $\mathrm{NH})$. The maximum photochemical efficiency of PSII $\left(\mathrm{F}_{\mathrm{v}} / \mathrm{F}_{\mathrm{m}}\right)$ was measured by dark adapting leaves attached to the tree using a dark adaption clip for $4 \mathrm{~h}$ (FL-DC; Opti-Sciences). The dark adaption period, which can be affected by species and plant light history, was determined a priori where the chosen time had the greatest $F_{v} / F_{m}$ values and $F_{v} / F_{m}$ did not change with longer dark adaption periods. $\mathrm{F}_{\mathrm{v}}$ represents maximum variable fluorescence yield in the dark-adapted state and $\mathrm{F}_{\mathrm{m}}$ maximum chlorophyll fluorescence yield in the dark-adapted state. Modulating light intensity was set at $10 \%$, saturating light intensity at $25 \%$, detector gain at two, and flash width was $1.2 \mathrm{~s}$. ФPSII was calculated from measurements on lightexposed leaves assumed to have reached steadystate conditions for at least 20 min under ambient photosynthetic photon flux density $(P P F D)$ at the time of measurement (Eq. [1]).

$$
\Phi \text { PSII }=\left(F_{m},-F_{s}\right) / F_{m},
$$

where $F_{s}$ represents steady-state fluorescence in the light-adapted state and $\mathrm{Fm}^{\prime}$ is maximum chlorophyll fluorescence yield in the light-adapted state. The fluorometer was set at 50\% modulating light intensity, $50 \%$ saturating light intensity, with far-red setup switched on at $100 \%$ intensity for $5 \mathrm{~s}$ and $2 \mathrm{~s}$ flash width. Leaf spectral reflectance was 
measured using a portable narrow-bandwidth leaf spectrometer (CI-710; CID Bio-Science, Camas, WA) in reflectance mode. Integration time was set to $300 \mathrm{~ms}$, boxcar width was 10 , and five scans were used to generate average values per leaf. The parameter calculated from measurements with the leaf spectrometer was PRI (Eq. [2]). PRI is related to photosynthetic light use efficiency; values for this index range from -1.0 to +1.0 , with the common range for green vegetation between -0.2 and 0.2 (Gamon et al., 1992).

$P R I=\left(W_{531 n m}-W_{570 n m}\right) /\left(531_{n m}+570_{n m}\right)$

where $W$ indicates intensity value at each wavelength. $\triangle \mathrm{PRI}$ was calculated from PRI data to represent the diurnal magnitude of xanthophyll pigment interconversion (Magney et al., 2016) (Eq. [3]). PRI values from 1000, 1200,1400 , and $1600 \mathrm{HR}\left(\mathrm{PRI}_{\mathrm{t}}\right)$ were subtracted from PRI measured at $0800 \mathrm{HR}\left(\mathrm{PRI}_{\mathrm{o}}\right)$ before xanthophyll de-epoxidation.

$$
\triangle P R I=P R I_{t}-P R I_{0}
$$

Leaf gas exchange. Leaf gas exchange was measured using a leaf chamber fluorometer attached to an IR gas analyzer (LI6400XT; Li-COR, Lincoln, NE). Reference carbon dioxide concentration was set at 400 ppm, leaf temperature at $25{ }^{\circ} \mathrm{C}$, the flow rate at $400 \mu \mathrm{mol} \cdot \mathrm{s}^{-1}$, and $P P F D$ was set at 1500 $\mu \mathrm{mol} \cdot \mathrm{m}^{-2} \cdot \mathrm{s}^{-1}$.

Plant water status. Pre-dawn leaf water potential $\left(\Psi_{\mathrm{pd}}\right)$, leaf water potential $\left(\Psi_{1}\right)$, and midday stem water potential $\left(\Psi_{\mathrm{md}}\right)$ were measured using a Scholander pressure chamber (3005 Series; Soilmoisture Equipment Corp, Goleta, CA). $\Psi_{\text {pd }}$ was measured before dawn (0400 to $0430 \mathrm{HR}$ ) on an uncovered leaf. $\Psi_{1}$ was measured from a fully sun-exposed leaf from the top of the tree canopy and assumed to have reached photosynthetic steady state for at least $20 \mathrm{~min}$. $\Psi_{\text {md }}$ was measured at about solar noon. Leaves used for measurement of $\Psi_{\mathrm{md}}$ were bagged for at least $1 \mathrm{~h}$ in silver reflective bags to equalize the leaf and xylem water potential before measurements were taken at 1315 to $1400 \mathrm{HR}$. Leaves that were used for $\Psi_{\text {md }}$ were sampled in the lower interior canopy close to the central leader or a scaffold branch.

\section{Data analysis}

Two-sample $t$ tests were performed at each time point for each parameter measured to determine treatment differences using SAS Enterprise Guide 7.1 (SAS Institute Inc., Cary, NC).

\section{Results}

\section{Environmental conditions}

Historical weather data from the five previous growing seasons showed the number of days reaching the $30{ }^{\circ} \mathrm{C}$ threshold (for apple leaf photosynthesis) from 1 Apr. until 30 Sept. was $55,68,59,74$, and 50 , respectively (data not shown). At the location of this study, about one-third of the days during the growing season experienced heat stress. Daily average maximum $P P F D$ collected from the control treatment during the growing season in 2015 and 2016 was 1775 and $1772 \mu \mathrm{mol} \cdot \mathrm{m}^{-2} \cdot \mathrm{s}^{-1}$, respectively, which is more than double the light saturation for maximal photosynthesis in apple (Campbell et al., 1992; Husen and Dequan 2002; Tartachnyk and Blanke, 2004).

The maximum ambient temperature was $38.1,33.7$, and $26.6{ }^{\circ} \mathrm{C}$ on days when the ambient temperature was high, moderate, or

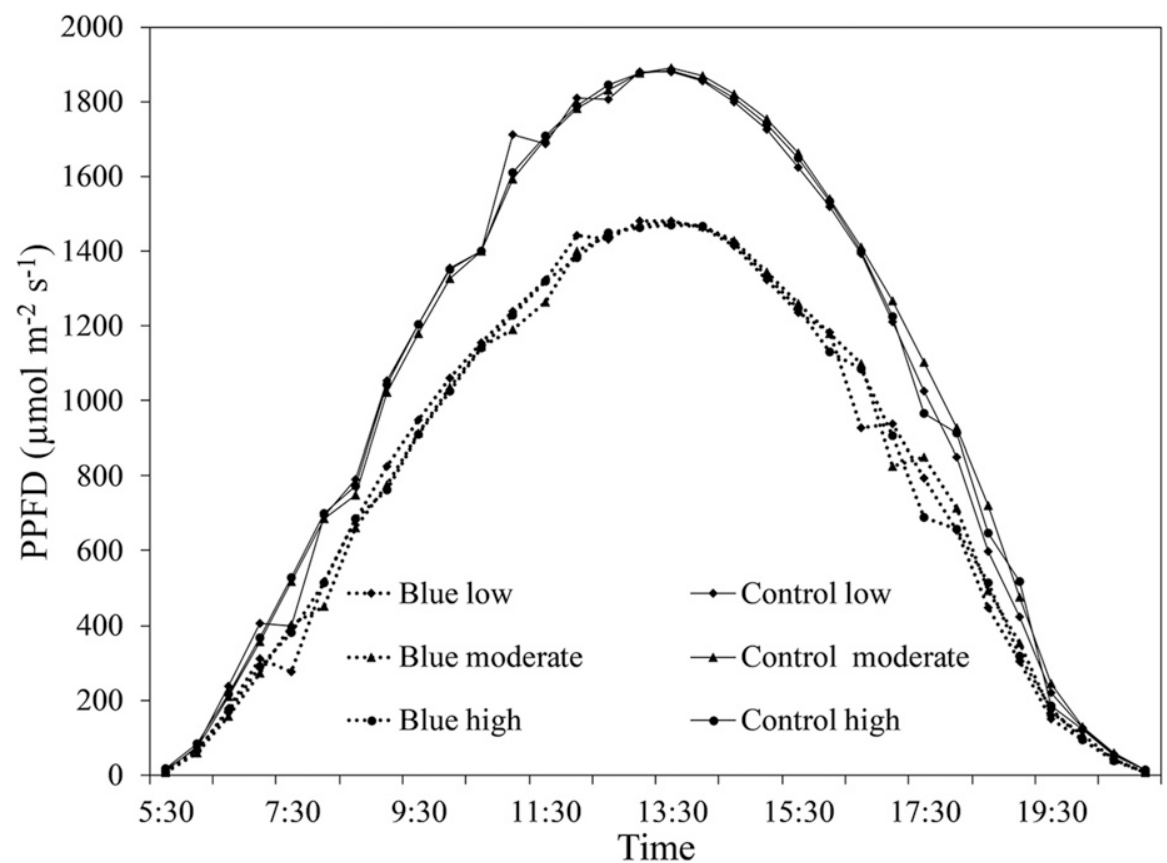

Fig. 1. Above-canopy photosynthetic photon flux density $(P P F D)$ under blue photoselective protective netting and an uncovered control measured during days with low $\left(26.6^{\circ} \mathrm{C}\right)$, moderate $\left(33.7^{\circ} \mathrm{C}\right)$, or high $\left(38.1^{\circ} \mathrm{C}\right)$ ambient temperature at Washington State University Tree Fruit Research and Extension Center, Wenatchee, WA.

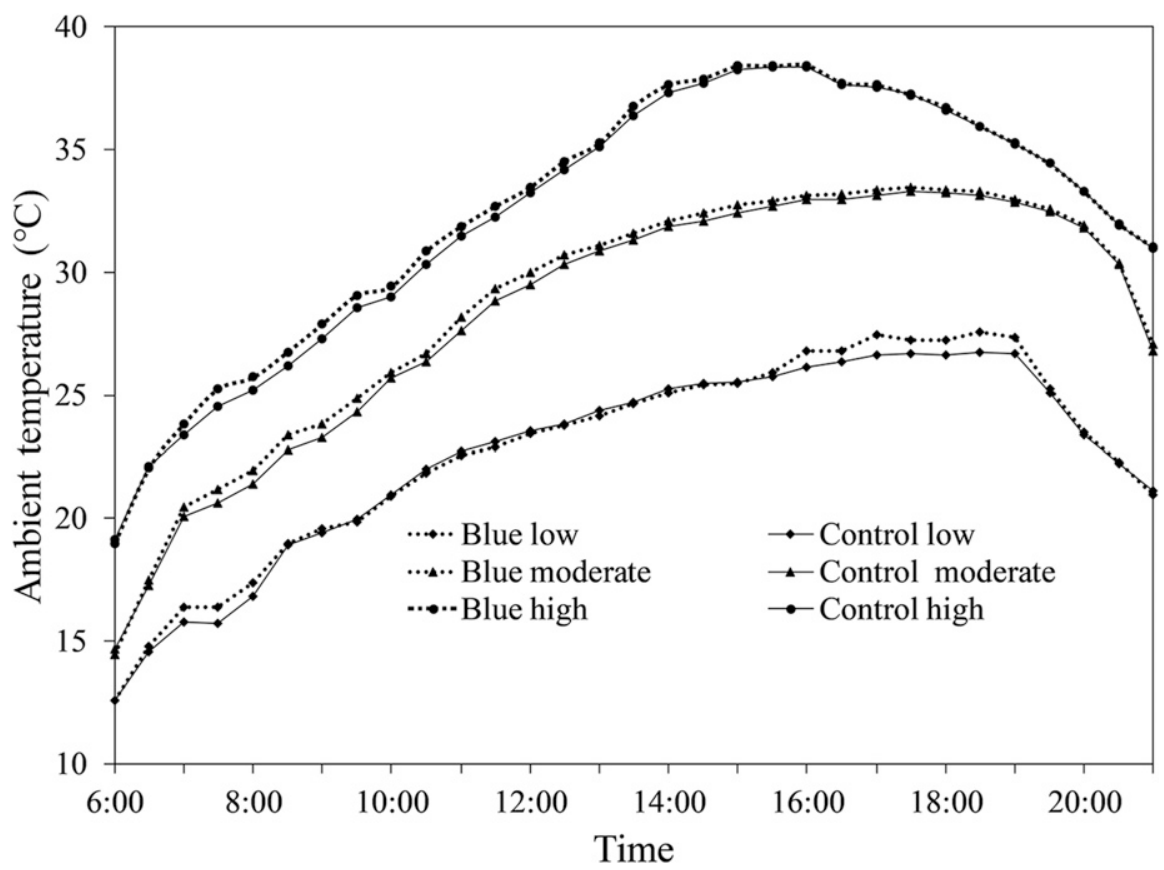

Fig. 2. Above-canopy ambient temperature under blue photoselective protective netting and an uncovered control measured during days with low $\left(26.6{ }^{\circ} \mathrm{C}\right)$, moderate $\left(33.7^{\circ} \mathrm{C}\right)$, or high $\left(38.1{ }^{\circ} \mathrm{C}\right)$ ambient temperature at Washington State University Tree Fruit Research and Extension Center, Wenatchee, WA. 
reached $30{ }^{\circ} \mathrm{C}$ at $\approx 1030 \mathrm{HR}$ and stayed above this threshold until $2130 \mathrm{HR}$ (Fig. 2). This indicates that trees experienced heat stress for $\approx 11 \mathrm{~h}$ on that particular day. For the day with moderate ambient temperature, the abovecanopy ambient temperature reached $30{ }^{\circ} \mathrm{C}$ at $\approx 1230 \mathrm{HR}$ and stayed above this threshold until $2030 \mathrm{HR}$, experiencing heat stress for $\approx 8 \mathrm{~h}$ for that particular day (Fig. 2). There were no significant differences in soil moisture content between treatments on measurement days (data not shown).

\section{Chlorophyll fluorescence and leaf spectral reflectance}

There were no significant differences between treatments in $\mathrm{F}_{\mathrm{v}} / \mathrm{F}_{\mathrm{m}}$ at 0800,1000 , 1200 , and $1600 \mathrm{HR}$ on the days with low or moderate ambient temperature (Fig. 3). At $1400 \mathrm{HR}$, both days with low or moderate ambient temperature had a significantly greater $F_{v} / F_{m}$ under blue photoselective PN compared with an uncovered control (Fig. 3). $\mathrm{F}_{\mathrm{v}} / \mathrm{F}_{\mathrm{m}}$ was significantly greater under the blue photoselective $\mathrm{PN}$ at all sampling time points compared with the control on the day when the ambient temperature was high (Fig. 3). Values of $\mathrm{F}_{\mathrm{v}} / \mathrm{F}_{\mathrm{m}}$ under 0.79 are considered unhealthy; the control reached this threshold at $1000 \mathrm{HR}$ on the day when the ambient temperature was high, whereas under blue photoselective $\mathrm{PN}$, this occurred later at $\approx 1200$ HR. $\mathrm{F}_{\mathrm{v}} / \mathrm{F}_{\mathrm{m}}$ on days when the ambient temperature was low or moderate reached the 0.79 threshold later in the day compared with the day when the ambient temperature was high. $\mathrm{F}_{\mathrm{v}} / \mathrm{F}_{\mathrm{m}}$ recovered at $1600 \mathrm{HR}$ on the

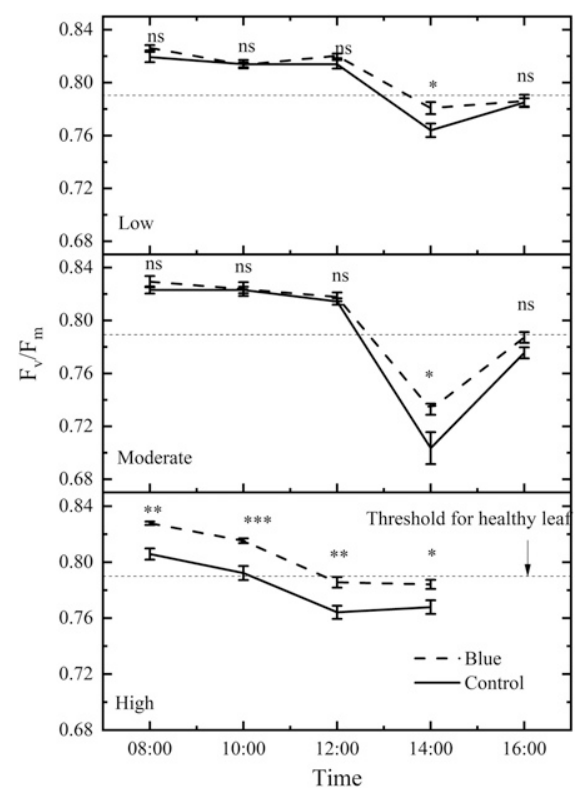

Fig. 3. Diurnal change in maximum photochemical efficiency of photosystem II $\left(\mathrm{F}_{\mathrm{v}} / \mathrm{F}_{\mathrm{m}}\right)$ of 'Honeycrisp' apple during days with low $\left(26.6^{\circ} \mathrm{C}\right)$, moderate $\left(33.7^{\circ} \mathrm{C}\right)$, or high $\left(38.1^{\circ} \mathrm{C}\right)$ ambient temperature under blue photoselective protective netting and an uncovered control. Means \pm SE at each sampling time point were separated by a two-sample $t$ test (ns $=$ not significant, $* P \leq 0.05,{ }^{* *} P \leq 0.001, * * * P \leq$ $0.0001)$ days when the ambient temperature was either low or moderate since light intensity was lower late in the afternoon. $\mathrm{F}_{\mathrm{v}} / \mathrm{F}_{\mathrm{m}}$ at $1600 \mathrm{HR}$ on the day when the ambient temperature was high could not be obtained due to the equipment overheating.

ФPSII was significantly lower in the control compared with blue photoselective $\mathrm{PN}$ at 0800,1200 , and $1600 \mathrm{HR}$ on a hot day and at 0800,1000 , and $1600 \mathrm{HR}$ on the days with moderate ambient temperature (Fig. 4). In general, for both treatments, ФPSII decreased with increasing light stress. Leaflevel photosynthetic light use efficiency as measured by $\triangle \mathrm{PRI}$ was significantly better under blue photoselective PN compared with the control on the day when the ambient temperature was high (Fig. 5). On the day with moderate ambient temperature, there were no differences in $\triangle P R I$ between treatments across all sampling times. $\triangle$ PRI was significantly greater under blue photoselective $\mathrm{PN}$ at 1200 HR compared with an uncovered control on a low day, with no significant difference being obtained at other sampling time points.

\section{Leaf gas exchange}

There were no significant differences in net carbon assimilation rate $(A)$, stomatal conductance $\left(g_{\mathrm{S}}\right)$, and leaf transpiration rate $(E)$ between treatments at all the sampling time points on a low day (Tables 1-3). On a moderate day, $A$ was significantly greater under the uncovered control compared with blue photoselective $\mathrm{PN}$ at $0800 \mathrm{HR}$, with no differences between treatments at 1000 , 1200, 1400, and 1600 HR (Table 1). There were no significant differences in $g_{S}$ between treatments at all the sampling time points on a moderate day (Table 2 ). $E$ was significantly lower under blue photoselective PN compared with an uncovered control at 0800 and $1200 \mathrm{HR}$ on the day with moderate ambient temperature, with no differences between treatments at 1000 , 1400 , and $1600 \mathrm{HR}$ (Table 3 ). $A$ was significantly greater under blue photoselective PN compared with an uncovered control at 0800 and $1200 \mathrm{HR}$ on the day with high ambient temperature, with no differences between treatments at 1000,1400 , and 1600 HR (Table 1). On the day with high ambient temperature, $g_{\mathrm{S}}$ and $E$ were significantly greater under blue photoselective PN compared with an uncovered control at $1000 \mathrm{HR}$, with no differences between treatments at 0800,1200, 1400, and 1600 HR (Tables 2 and 3).

\section{Plant water status}

There was no significant difference in $\Psi_{\mathrm{pd}}$ between the treatments for all the measurement days (data not shown). No significant differences in $\Psi_{1}$ were obtained between treatments on a low day (Fig. 6). On the day with moderate ambient temperature, $\Psi_{1}$ was significantly more negative in the control at $0800 \mathrm{HR}$ in the control compared with blue photoselective $\mathrm{PN}$, with no significant differences between treatments observed at 1000, 1200, 1400, and 1600 HR (Fig. 6). On the day with high ambient temperature, $\Psi_{1}$ was significantly more negative in the control at 0800

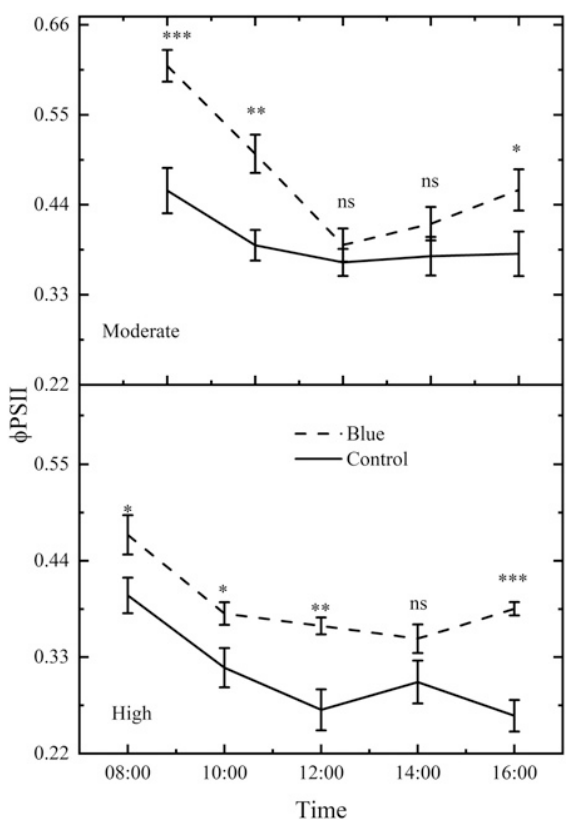

Fig. 4. Diurnal change in quantum photosynthetic yield of photosystem II (ФPSII) of 'Honeycrisp' apple during days with moderate $\left(33.7^{\circ} \mathrm{C}\right)$ or high $\left(38.1{ }^{\circ} \mathrm{C}\right)$ ambient temperature under blue photoselective protective netting and an uncovered control. Means \pm SE at each sampling time point were separated by a two-sample $t$ test (ns $=$ not significant, ${ }^{*} P \leq$ $\left.0.05,{ }^{* *} P \leq 0.001,{ }^{* * *} P \leq 0.0001\right)$.

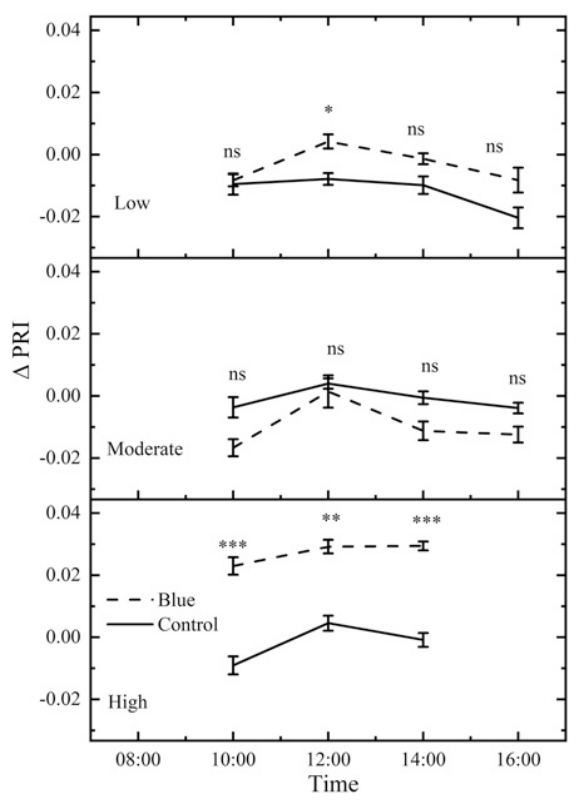

Fig. 5. Diurnal change in photochemical reflectance index ( $\triangle \mathrm{PRI})$ of 'Honeycrisp' apple during days with low $\left(26.6^{\circ} \mathrm{C}\right)$, moderate $\left(33.7^{\circ} \mathrm{C}\right)$, or high $\left(38.1^{\circ} \mathrm{C}\right)$ ambient temperature under blue photoselective protective netting and an uncovered control. Means $\pm \mathrm{SE}$ at each sampling time point were separated by a two-sample $t$ test (ns $=$ not significant, $* P \leq$ $0.05, * * P \leq 0.001, * * * P \leq 0.0001)$

and 1200 HR compared with blue photoselective PN. $\Psi_{\text {md }}$ was significantly more negative in the control compared with blue photoselective PN on the days in which the ambient 
Table 1. Diurnal change in net carbon assimilation rate $\left(\mu \mathrm{mol} \cdot \mathrm{m}^{-2} \cdot \mathrm{s}^{-1}\right)$ of 'Honeycrisp' apple under blue photoselective protective netting and an uncovered control at Washington State University Tree Fruit Research and Extension Center, Wenatchee, WA. ${ }^{\mathrm{z}}$

\begin{tabular}{lccccc}
\hline Treatment & $0800 \mathrm{HR}$ & $1000 \mathrm{HR}$ & $1200 \mathrm{HR}$ & $1400 \mathrm{HR}$ & $1600 \mathrm{HR}$ \\
\hline Low & & & & & \\
$\quad$ Blue & $12.94 \pm 0.78$ & $11.99 \pm 0.77$ & $13.45 \pm 1.60$ & $15.3 \pm 1.02$ & $4.89 \pm 1.13$ \\
$\quad$ Control & $14.89 \pm 1.03$ & $14.18 \pm 10.00$ & $14.11 \pm 1.22$ & $12.15 \pm 1.36$ & $6.59 \pm 1.11$ \\
$P$ value & $\mathrm{NS}$ & $\mathrm{NS}$ & $\mathrm{NS}$ & $\mathrm{NS}$ & $\mathrm{NS}$ \\
Moderate & & & & & \\
$\quad$ Blue & $12.19 \pm 1.07$ & $14.69 \pm 0.67$ & $9.88 \pm 0.47$ & $12.19 \pm 1.51$ & $8.9 \pm 0.88$ \\
$\quad$ Control & $15.49 \pm 0.74$ & $16.44 \pm 0.96$ & $11.08 \pm 0.67$ & $12.43 \pm 1.51$ & $10.22 \pm 1.23$ \\
$P$ value & $*$ & $\mathrm{NS}$ & $\mathrm{NS}$ & $\mathrm{NS}$ & $\mathrm{NS}$ \\
High & & & & & \\
Blue & $16.53 \pm 1.63$ & $10.97 \pm 1.29$ & $11.08 \pm 0.78$ & $7.97 \pm 0.97$ & $5.29 \pm 0.51$ \\
$\quad$ Control & $11.95 \pm 1.69$ & $9.40 \pm 1.39$ & $6.86 \pm 0.80$ & $6.11 \pm 0.97$ & $5.01 \pm 0.71$ \\
$P$ value & $*$ & $\mathrm{NS}$ & $* *$ & $\mathrm{NS}$ & $\mathrm{NS}$ \\
\hline z & & & & &
\end{tabular}

${ }^{\mathrm{z}}$ Means \pm SE at each sampling time point were separated by a two-sample $t$ test (NS $=$ not significant, ${ }^{*} P \leq$ $\left.0.05,{ }^{* *} P \leq 0.001, * * * P \leq 0.0001\right)$.

Table 2. Diurnal change in stomatal conductance $\left(\mathrm{mol} \cdot \mathrm{m}^{-2} \cdot \mathrm{s}^{-1}\right)$ of 'Honeycrisp' apple during days with low $\left(26.6^{\circ} \mathrm{C}\right)$, moderate $\left(33.7^{\circ} \mathrm{C}\right)$, or high $\left(38.1^{\circ} \mathrm{C}\right)$ ambient temperature under blue photoselective protective netting and an uncovered control at Washington State University Tree Fruit Research and Extension Center, Wenatchee, WA. ${ }^{\mathrm{z}}$

\begin{tabular}{cccccc}
\hline Treatment & $0800 \mathrm{HR}$ & $1000 \mathrm{HR}$ & $1200 \mathrm{HR}$ & $1400 \mathrm{HR}$ & $1600 \mathrm{HR}$ \\
\hline Low & & & & & \\
$\quad$ Blue & $0.16 \pm 0.01$ & $0.14 \pm 0.01$ & $0.14 \pm 0.02$ & $0.10 \pm 0.01$ & $0.06 \pm 0.01$ \\
$\quad \begin{array}{c}\text { Control } \\
\text { P value }\end{array}$ & $0.20 \pm 0.02$ & $0.15 \pm 0.01$ & $0.14 \pm 0.02$ & $0.10 \pm 0.02$ & $0.08 \pm 0.02$ \\
Moderate & $\mathrm{NS}$ & $\mathrm{NS}$ & $\mathrm{NS}$ & $\mathrm{NS}$ & $\mathrm{NS}$ \\
$\quad$ Blue & $0.21 \pm 0.02$ & $0.17 \pm 0.01$ & $0.11 \pm 0.01$ & $0.11 \pm 0.01$ & $0.10 \pm 0.01$ \\
$\quad$ Control & $0.26 \pm 0.02$ & $0.18 \pm 0.01$ & $0.13 \pm 0.01$ & $0.11 \pm 0.02$ & $0.12 \pm 0.01$ \\
$P$ value & $\mathrm{NS}$ & $\mathrm{NS}$ & $\mathrm{NS}$ & $\mathrm{NS}$ & $\mathrm{NS}$ \\
High & & & & & \\
$\quad$ Blue & $0.18 \pm 0.03$ & $0.20 \pm 0.02$ & $0.08 \pm 0.01$ & $0.08 \pm 0.01$ & $0.06 \pm 0.01$ \\
$\quad$ Control & $0.15 \pm 0.02$ & $0.09 \pm 0.01$ & $0.07 \pm 0.01$ & $0.07 \pm 0.01$ & $0.07 \pm 0.01$ \\
$P$ value & $\mathrm{NS}$ & $* *$ & $\mathrm{NS}$ & $\mathrm{NS}$ & $\mathrm{NS}$ \\
\hline
\end{tabular}

${ }^{\mathrm{z}}$ Means \pm SE at each sampling time point were separated by a two-sample $t$ test (NS $=$ not significant, ${ }^{*} P \leq$ $0.05, * * P \leq 0.001, * * * P \leq 0.0001)$

Table 3. Diurnal change in leaf transpiration rate $\left(\mathrm{mol} \cdot \mathrm{m}^{-2} \cdot \mathrm{s}^{-1}\right)$ of 'Honeycrisp' apple during days with low $\left(26.6{ }^{\circ} \mathrm{C}\right)$, moderate $\left(33.7^{\circ} \mathrm{C}\right)$, or high $\left(38.1{ }^{\circ} \mathrm{C}\right)$ ambient temperature under blue photoselective protective netting and an uncovered control at Washington State University Tree Fruit Research and Extension Center, Wenatchee, WA. ${ }^{\mathrm{z}}$

\begin{tabular}{cccccc}
\hline Treatment & $0800 \mathrm{HR}$ & $1000 \mathrm{HR}$ & $1200 \mathrm{HR}$ & $1400 \mathrm{HR}$ & $1600 \mathrm{HR}$ \\
\hline Low & & & & & \\
$\quad$ Blue & $3.15 \pm 0.22$ & $2.77 \pm 0.15$ & $2.85 \pm 0.27$ & $2.89 \pm 0.35$ & $1.80 \pm 0.23$ \\
Control & $3.84 \pm 0.28$ & $2.94 \pm 0.18$ & $3.08 \pm 0.29$ & $2.68 \pm 0.37$ & $2.26 \pm 0.25$ \\
$P$ value & $\mathrm{NS}$ & $\mathrm{NS}$ & $\mathrm{NS}$ & $\mathrm{NS}$ & $\mathrm{NS}$ \\
Moderate & & & & & \\
$\quad$ Blue & $4.32 \pm 0.33$ & $4.08 \pm 0.27$ & $3.84 \pm 0.21$ & $4.07 \pm 0.52$ & $4.10 \pm 0.32$ \\
$\quad$ Control & $5.29 \pm 0.27$ & $4.37 \pm 0.22$ & $4.64 \pm 0.21$ & $4.20 \pm 0.58$ & $4.66 \pm 0.45$ \\
$P$ value & $*$ & $\mathrm{NS}$ & $*$ & $\mathrm{NS}$ & $\mathrm{NS}$ \\
High & & & & & \\
$\quad$ Blue & $3.77 \pm 0.47$ & $5.62 \pm 0.44$ & $3.55 \pm 0.30$ & $4.45 \pm 0.59$ & $3.69 \pm 0.23$ \\
$\quad$ Control & $3.50 \pm 0.40$ & $3.10 \pm 0.43$ & $3.40 \pm 0.34$ & $4.30 \pm 0.39$ & $4.06 \pm 0.54$ \\
$P$ value & $\mathrm{NS}$ & $* *$ & $\mathrm{NS}$ & $\mathrm{NS}$ & $\mathrm{NS}$ \\
\hline
\end{tabular}

${ }^{\mathrm{z}}$ Means \pm SE at each sampling time point were separated by a two-sample $t$ test (NS $=$ not significant, ${ }^{*} P \leq$ $0.05, * * P \leq 0.001, * * * P \leq 0.0001)$.

temperature was low and high (Fig. 7). However, there were no significant differences between treatments observed on the day with moderate ambient temperature.

\section{Discussion}

\section{Environmental conditions}

Previous studies have reported that light and $\mathrm{CO}_{2}$-saturated photosynthesis was maximal at $30^{\circ} \mathrm{C}$ in field-grown 'Royal Gala' and 'Braestar' apple trees (Gindaba and Wand, 2007b; Pretorius and Wand, 2003). From the historical weather data in Wenatchee, WA, it is apparent that trees experience heat stress and Schrader, 2012). PN represents a potential way to alleviate tree stress without the limitations of evaporative cooling and reflective particle films. $P P F D$ was significantly reduced under blue photoselective $\mathrm{PN}$ by on average $22 \%$ during peak light intensity in the afternoon during the measurement days. In our experiments, trees under blue photoselective PN demonstrated indicators of reduced light stress compared with the control despite consistent light intensity across the measurement days. The above-canopy ambient temperature was not different in the blue photoselective PN treatment irrespective of ambient temperature on the day of measurement, as also reported by Kalcsits et al. (2017). Although still experiencing the same ambient temperature during the experiment as the control, trees under blue photoselective PN were exposed to lower light stress. Reduced exposure to excess light under PN likely improved light use efficiency due to a reduction in photoinhibition.

Although there was no replication of netted and non-netted treatments, in our experiments, peak $P P F D$ was $\approx 1470 \mu \mathrm{mol} \cdot \mathrm{m}^{-2} \cdot \mathrm{s}^{-1}$ under blue PN compared with $\approx 1880 \mu \mathrm{mol} \cdot \mathrm{m}^{-2} \cdot \mathrm{s}^{-1}$ for the uncovered control for the clear sky measurement days. This was consistent with data provided in Kalcsits et al. (2017). Light saturation for photosynthesis in apple has been reported to be $\approx 700$ to $800 \mu \mathrm{mol} \cdot \mathrm{m}^{-2} \cdot \mathrm{s}^{-1}$ in 'Braeburn' (Tartachnyk and Blanke, 2004) and $800 \mu \mathrm{mol} \cdot \mathrm{m}^{-2} \cdot \mathrm{s}^{-1}$ in 'Stayman', 'Red Prince Delicious', and 'Tengmu' cultivars (Campbell et al., 1992; Husen and Dequan 2002). Consequently, even though there was a reduction in PPFD under blue photoselective PN, light levels exceeded the saturation point needed for maximum photosynthesis. $P P F D$ reached the $800 \mu \mathrm{mol} \cdot \mathrm{m}^{-2} \cdot \mathrm{s}^{-1}$ threshold for maximal photosynthesis at $\approx 0830 \mathrm{HR}$ in the control and $0900 \mathrm{HR}$ under blue PN and stayed above this threshold until 1800 and $1730 \mathrm{HR}$, respectively. This indicates that trees experienced some degree of light stress for $9.5 \mathrm{~h}$ in the control and $8.5 \mathrm{~h}$ under blue PN on a clear sunny day.

\section{Chlorophyll fluorescence and leaf spectral}

According to Murata et al. (2007), the extent of photoinhibition depends on the balance between photodamage to PSII and the repair of such damage. There are two types of photoinhibition-chronic inhibition, which results in a long-term prolonged decrease in $\mathrm{F}_{\mathrm{v}} / \mathrm{F}_{\mathrm{m}}$, and dynamic photoinhibition, which manifests as a diurnal decline in $\mathrm{F}_{\mathrm{v}} / \mathrm{F}_{\mathrm{m}}$ that is fully reversible overnight (Werner at al., 2002). In our study, 'Honeycrisp' exhibited dynamic photoinhibition as shown by the diurnal decline in $F_{v /} F_{m}$ that was fully reversible overnight as measured at 0800 HR. The decline in $F_{v} / F_{m}$ coincided with the peak of solar radiation as measures by PPFD. Even though, $\mathrm{F}_{\mathrm{v}} / \mathrm{F}_{\mathrm{m}}$ declined below the optimal threshold of 0.79 on days with low or moderate ambient temperature in both treatments, the reduction in light intensity under blue photoselective $\mathrm{PN}$ resulted in better light utilization, as shown by the 


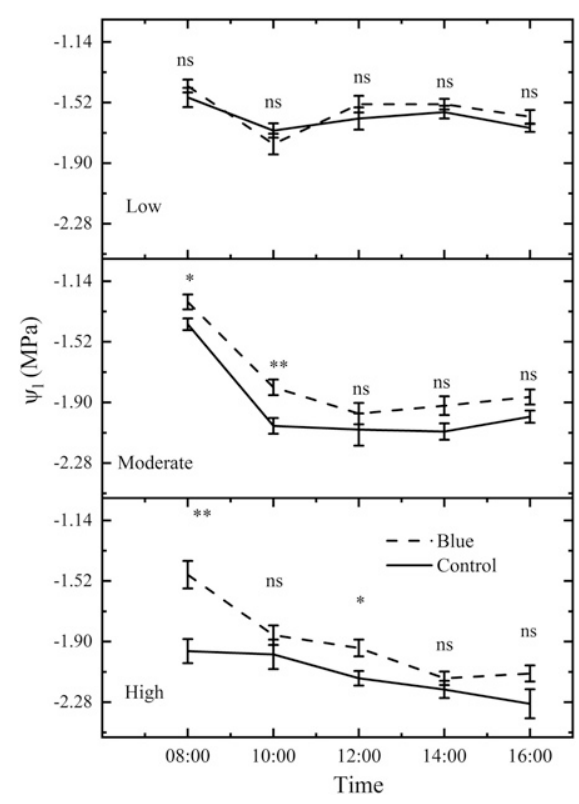

Fig. 6. Diurnal change in leaf water potential $\left(\Psi_{1}\right)$ of 'Honeycrisp' apple during days with low $\left(26.6^{\circ} \mathrm{C}\right)$, moderate $\left(33.7^{\circ} \mathrm{C}\right)$, or high $\left(38.1^{\circ} \mathrm{C}\right)$ air temperature under blue photoselective protective netting compared with an uncovered control. Means \pm SE at each sampling time point were separated by a two-sample $t$ test (ns $=$ not significant, ${ }^{*} P \leq 0.05,{ }^{*} P \leq 0.0001, * * * P \leq$ $0.001)$.

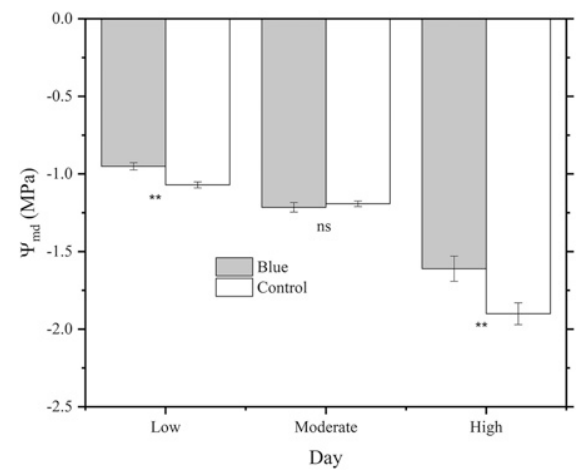

Fig. 7. Midday stem water potential $\left(\Psi_{\mathrm{md}}\right)$ of 'Honeycrisp' apple during days with low $\left(26.6{ }^{\circ} \mathrm{C}\right)$, moderate $\left(33.7{ }^{\circ} \mathrm{C}\right)$, or high $\left(38.1{ }^{\circ} \mathrm{C}\right)$ ambient temperature under blue photoselective PN compared with an uncovered control. Means $\pm \mathrm{SE}$ at each sampling time point were separated by a two-sample $t$ test (ns $=$ not significant, ${ }^{*} P \leq 0.05,{ }^{* *} P \leq 0.001$, $* * * P \leq 0.0001)$.

significantly greater $\mathrm{F}_{\mathrm{v}} / \mathrm{F}_{\mathrm{m}}$ values. The combination of heat and light stress on the day with high ambient temperature increased the rate of photoinhibition, as shown by the faster diurnal decline in $\mathrm{F}_{\mathrm{v}} / \mathrm{F}_{\mathrm{m}}$. The reduction in light intensity under blue photoselective PN during heat stress conditions delayed the time to reach the 0.79 threshold for stressed leaves $(\approx 1200 \mathrm{HR})$ compared with $\approx 1000 \mathrm{HR}$ for the uncovered control. Under blue photoselective $\mathrm{PN}$, based on $\mathrm{F}_{\mathrm{v}} / \mathrm{F}_{\mathrm{m}}$ measurements, leaves were able to use light more efficiently compared with those that were uncovered and exposed to full sun.
ФPSII can provide a measure of the amount of energy used in photochemistry by PSII under steady-state photosynthetic lighting conditions (Maxwell and Johnson, 2000). ФPSII was sensitive to increased light stress, as shown by the diurnal decline with increasing light intensity. ФPSII was greater under blue photoselective PN compared with the uncovered control on the days when ambient temperature was either moderate or high. Results for $\Phi$ PSII are not available for the day when ambient temperature was low due to equipment malfunction.

No differences in $\triangle P R I$ were observed on days with low or moderate ambient temperature. On the day with high ambient temperature, $\triangle \mathrm{PRI}$ was significantly greater at all the sampling times under blue photoselective PN compared with the uncovered control. PRI is a physiological index that is used to measure light efficiency in plants by measuring xanthophyll cycle activity (Gamon et al., 1992). $\triangle$ PRI represents the diurnal magnitude of xanthophyll pigment interconversion and is sensitive to light stress (Magney et al., 2016). Trees under blue photoselective PN had greater leaf-level photosynthetic light use efficiency compared with the control under heat stress conditions as measured by leaf spectral reflectance

\section{Leaf gas exchange}

The better leaf-level photosynthetic light use efficiency observed under blue photoselective PN did not consistently result in increased $A$. $A$ decreased by more than $50 \%$ in both treatments on the day when the ambient temperature was high while generally remaining constant on the days with low or moderate ambient temperature. Under heat stress, the reduction in photosynthesis in apple leaves is due to the negative effect on $g_{\mathrm{S}}$, the detrimental effect of heat on ribulose1,5-bisphosphate (RuBP) carboxylation and on ribulose-1,5-bisphosphate regeneration (Greer, 2015). On the day with high ambient temperature, $A$ was significantly greater under blue photoselective $\mathrm{PN}$ at 0800 and 1200 HR compared with the uncovered control. Previous results on the effect of PN on $A$ in apple have been variable, probably because some experiments were done under ambient conditions and some under controlled conditions. For example, Solomakhin and Blanke (2008) reported that leaf photosynthesis is not generally hampered under a photoselective PN but is reduced when the amount of light falls below light saturation of 800 $\mu \mathrm{mol} \cdot \mathrm{m}^{-2} \cdot \mathrm{s}^{-1} P A R$. No differences in photosynthetic rates in 'Fuji' were observed under ambient light on a sunny day between $23 \%$ green-black PN $\left(2000 \mu \mathrm{mol} \cdot \mathrm{m}^{-2} \cdot \mathrm{s}^{-1} \mathrm{PAR}\right)$ and uncovered control $\left(2200 \mu \mathrm{mol} \cdot \mathrm{m}^{-2} \cdot \mathrm{s}^{-1}\right.$ $P A R$ ) (Solomakhin and Blanke, 2008). Under cloudy conditions, the $23 \%$ green-black PN $\left(340 \mu \mathrm{mol} \cdot \mathrm{m}^{-2} \cdot \mathrm{s}^{-1} \mathrm{PAR}\right)$ reduced leaf photosynthesis by $21 \%$ compared with an uncovered control $\left(385 \mu \mathrm{mol} \cdot \mathrm{m}^{-2} \cdot \mathrm{s}^{-1} P A R\right)$. Bastías et al., (2012) reported that photosynthesis in 'Fuji' at controlled and saturated $P P F D$ $\left(1250 \mu \mathrm{mol} \cdot \mathrm{m}^{-2} \cdot \mathrm{s}^{-1}\right)$ was $28 \%$ greater under
$40 \%$ blue photoselective PN when compared with a $20 \%$ neutral white PN control. Photosynthesis in 'Royal Gala' measured at ambient temperature of 32 to $36{ }^{\circ} \mathrm{C}$ and ambient solar radiation $\left(1600-2100 \mu \mathrm{mol} \cdot \mathrm{m}^{-2} \cdot \mathrm{s}^{-1}\right.$ $P A R$ ) was significantly lower under $20 \%$ black PN compared with an uncovered control for one sampling date with no significant differences being observed on another day (Gindaba and Wand, 2007b). No significant differences in midday photosynthesis $(1200$ 1400 HR South Africa Standard Time) were reported between $20 \%$ black shade net and an uncovered control for 'Cripps' Pink' under ambient radiation (1700 to $2100 \mu \mathrm{mol} \cdot \mathrm{m}^{-2} \cdot \mathrm{s}^{-1}$ $P A R)$ and ambient temperature $\left(34\right.$ to $39^{\circ} \mathrm{C}$ ) (Gindaba and Wand, 2007a).

\section{Plant water status}

Plant water status is an important physiological indicator of stress in trees (Nadezhdina, 1999). There were no differences in $\Psi_{\mathrm{pd}}$ between treatments for all the measurement days. $\Psi_{\mathrm{pd}}$ is closely related to soil moisture level (Jones, 2007). Therefore, we can discount the effect of soil water deficits on our results. Results from $\Psi_{\mathrm{md}}$ showed that the control was significantly more stressed compared with blue photoselective PN on days with low or high ambient temperature, with no differences observed on the day with moderate ambient temperature. $\Psi_{\mathrm{md}}$ of 'Smothee Golden Delicious' was significantly less negative for trees under $30 \%$ blue, red, yellow, gray, pearl, and $12 \%$ white PN compared with an uncovered control (Shahak et al., 2004). $\Psi_{1}$, which is a less-reliable measure of tree stress (McCutchan and Shackel, 1992), also showed that trees under blue photoselective PN were less stressed compared with the uncovered control on days with either moderate or high ambient temperature, although not always significantly.

In conclusion, heat stress events occur regularly in the apple-growing regions in semiarid apple production areas in the world. The use of PN provides a potential way of reducing tree stress and increasing light use efficiency under heat stress conditions. Here, with limited replication of temperature and full light conditions, blue photoselective PN resulted in a more favorable environment due to the reduction in light stress. Although still experiencing the same amount of temperature stress, trees under blue photoselective PN were exposed to reduced light stress compared with the control. Plant water status was much better under PN, indicating reduced stress. Leaf-level photosynthetic light use efficiency measured by $\mathrm{F}_{\mathrm{v}} / \mathrm{F}_{\mathrm{m}}$ and $\Delta \mathrm{PRI}$ was better under blue photoselective $\mathrm{PN}$, most likely because of the reduction in photoinhibition. Future research should build on these results and scale up to the whole-tree level, looking at the impact of blue PN on whole tree assimilation, growth, and yield. As climate change increases the temperature stress experienced in traditional tree fruitgrowing regions, this work highlights the importance of understanding and mitigating the negative effects of the interaction between 
high light intensity and high ambient temperature on tree health and productivity.

\section{Literature Cited}

AgWeatherNet. 2017. AgWeatherNet Current Conditions Map. 24 Sept. 2017. <http://weather.wsu. edu/>.

Arthurs, S.P., R.H. Stamps, and F.F. Giglia. 2013. Environmental modification inside photoselective shadehouses. HortScience 48:975-979.

Ashraf, M. and P.J.C. Harris. 2013. Photosynthesis under stressful environments: An overview. Photosynthetica 51:163-190.

Bastías, R.M., L.C. Grappadelli, and L. Manfrini. 2012. Exploring the potential use of photoselective nets for fruit growth regulation in apple. Chil. J. Agr. Res. 72:224-231.

Berry, J.A. and O. Bjorkman. 1980. Photosynthetic response and adaptation to temperature in higher plants. Annu. Rev. Plant Physiol. 31:491-543.

Bita, C.E. and T. Gerats. 2013. Plant tolerance to high temperature in a changing environment: Scientific fundamentals and production of heat stress-tolerant crops. Front. Plant Sci. $4: 1-18$.

Campbell, R.J., R.P. Marini, and J.B. Birch. 1992. Canopy position affects light response curves for gas exchange characteristics of apple spur leaves. J. Amer. Soc. Hort. Sci. 117:467-472.

Castellano, S., A. Candura, and G. Scarascia Mugnozza. 2008. Relationship between solidity ratio, colour and shading effect of agricultural nets. Acta Hort. 801:253-258.

Ebert, G. and F. Casierra. 2000. Does netting always reduce the assimilation of apple trees? (Verringert die Einnetzung grundsätzlich die Assimilationsleistung von Apfelbäumen?). ErwerbsObstbau 42:12-14.

Evans, R.G. 2004. Energy balance of apples under evaporative cooling. Trans. ASAE 47:10291038.

Flanagan, L.B., E.J. Sharp, and J.A. Gamon. 2015. Application of the photosynthetic light-use efficiency model in a northern Great Plains grassland. Remote Sens. Environ. 168:239-251.

Gamon, J., J. Penuelas, and C. Field. 1992. A narrow-waveband spectral index that tracks diurnal changes in photosynthetic efficiency. Remote Sens. Environ. 41:35-44.

Gamon, J.A. and R.W. Pearcy. 1989. Photoinhibition in Vitis californica: The role of temperature during high-light treatment. Plant Physiol. 92:487-494.

Gindaba, J. and S.J.E. Wand. 2007a. Climateameliorating measures influence photosynthetic gas exchange of apple leaves. Ann. Appl. Biol. 150:75-80.

Gindaba, J. and S.J.E. Wand. 2007b. Do fruit sunburn control measures affect leaf photosynthetic rate and stomatal conductance in 'Royal Gala' apple? Environ. Exp. Bot. 59:160-165.

Glenn, D.M. and G.J. Puterka. 2005. Particle films: A new technology for agriculture. Hort. Rev. 31:1-44.

Greer, D.H. 2015. Seasonal changes in the photosynthetic response to $\mathrm{CO}_{2}$ and temperature in apple (Malus domestica cv. 'Red Gala') leaves during a growing season with a high temperature event. Funct. Plant Biol. 42:309-324.
Hatfield, J.L. and J.H. Prueger. 2015. Temperature extremes: Effect on plant growth and development. Weather Clim. Extrem. 10:4-10.

Havaux, M. 1996. Short-term responses of Photosystem I to heat stress. Induction of a PS II-independent electron transport through PS I fed by stromal components. Photosynth. Res. 47:85-97.

Husen, J. and L. Dequan. 2002. Relationship between photosystem 2 electron transport and photosynthetic $\mathrm{CO}_{2}$ assimilation responses to irradiance in young apple tree leaves. Photosynthetica 40:139-144.

Jones, H.G. 2007. Monitoring plant and soil water status: Established and novel methods revisited and their relevance to studies of drought tolerance. J. Expt. Bot. 58:119-130.

Kalcsits, L., S. Musacchi, D.R. Layne, G. Mupambi, S. Serra, T. Schmidt, M. Mendoza, L. Asteggiano, S. Sankaran, L. Khot, S. Jaralmasjed, and C. Zuniga. 2017. Above and below-ground environmental changes associated with the use of photoselective anti-hail netting in apple. Agr. For. Meteorol. 237/238:9-17.

Li, T. and Q. Yang. 2015. Advantages of diffuse light for horticultural production and perspectives for further research. Front. Plant Sci. 6:1-5.

Liu, L., Y. Zhang, Q. Jiao, and D. Peng. 2013. Assessing photosynthetic light-use efficiency using a solar-induced chlorophyll fluorescence and photochemical reflectance index. Intl. J. Remote Sens. 34:4264-4280.

Magney, T.S., L.A. Vierling, J.U. Eitel, D.R. Huggins, and S.R. Garrity. 2016. Response of high frequency photochemical reflectance index (PRI) measurements to environmental conditions in wheat. Remote Sens. Environ. 173:84-97.

Maxwell, K. and G.N. Johnson. 2000. Chlorophyll fluorescence - a practical guide. J. Expt. Bot. 51:659-668.

McCutchan, H. and K.A. Shackel. 1992. Stemwater potential as a sensitive indicator of water stress in prune trees (Prunus domestica L. cv. French). J. Amer. Soc. Hort. Sci. 117:607-611.

Middleton, S. and A. McWaters. 2002. Hail netting of apple orchards- Australian experience. Compact Fruit Tree. 35:51-55.

Mupambi, G., B.M. Anthony, D.R. Layne, S. Musacchi, S. Serra, T. Schmidt, and L.A. Kalcsits. 2018. The influence of protective netting on tree physiology and fruit quality of apple: A review. Scientia Hort. 236:60-72.

Murata, N., S. Takahashi, Y. Nishiyama, and S.I. Allakhverdiev. 2007. Photoinhibition of photosystem II under environmental stress. Biochim. Biophys. Acta, Bioenerg. 1767:414-421.

Nadezhdina, N. 1999. Sap flow index as an indicator of plant water status. Tree Physiol. 19:885-891.

Pretorius, J.J.B. and S.J.E. Wand. 2003. Lateseason stomatal sensitivity to microclimate is influenced by sink strength and soil moisture stress in 'Braestar' apple trees in South Africa. Scientia Hort. 98:157-171.

Racsko, J. and L.E. Schrader. 2012. Sunburn of apple fruit: Historical background, recent advances and future perspectives. Crit. Rev. Plant Sci. $31: 455-504$
Romo-Chacon, A., J.A. Oroczo-Avitia, A.A. Gardea, V. Guerrero-Prieto, and J.M. Soto-Parrra. 2007. Hail net effect on photosynthetic rate and fruit color development of 'Starkrimson' apple trees. J. Amer. Pomol. Soc. 61:174-178.

Salvucci, M.E. and S.J. Crafts-Brandner. 2004. Mechanism for deactivation of Rubisco under moderate heat stress. Physiol. Plant. 122:513519.

Seemann, J.R., J.A. Berry, and W.J.S. Downton. 1984. Photosynthetic response and adaptation to high temperature in desert plants: A comparison of gas exchange and fluorescence methods for studies of thermal tolerance. Plant Physiol. 75:364-368.

Shahak, Y., E.E. Gussakovsky, Y. Cohen, S. Lurie, R. Stern, S. Kfir, A. Naor, I. Atzmon, I. Doron, and Y. Greenblat-Avron. 2004. Colornets: A new approach for light manipulation in fruit trees. Acta Hort. 636:609-616.

Shahak, Y., E. Gal, Y. Offir, and D. Ben-Yakir. 2008. Photoselective shade netting integrated with greenhouse technologies for improved performance of vegetable and ornamental crops. Acta Hort. 797:75-80.

Shahak, Y., Y. Kong, and K. Ratner. 2016. The wonders of yellow netting. Acta Hort. 1134:327334.

Sharkey, T.D. 2005. Effects of moderate heat stress on photosynthesis: Importance of thylakoid reactions, rubisco deactivation, reactive oxygen species, and thermotolerance provided by isoprene. Plant Cell Environ. 28:269-277.

Solomakhin, A. and M.M. Blanke. 2008. Coloured hailnets alter light transmission, spectra and phytochrome, as well as vegetative growth, leaf chlorophyll and photosynthesis and reduce flower induction of apple. Plant Growth Regulat. 56:211-218.

Solomakhin, A. and M.M. Blanke. 2010. Can coloured hailnets improve taste (sugar, sugar: Acid ratio), consumer appeal (colouration) and nutritional value (anthocyanin, vitamin C) of apple fruit? Food Sci Technol. 43:1277-1284.

Tartachnyk, I.I. and M.M. Blanke. 2004. Effect of delayed fruit harvest on photosynthesis, transpiration and nutrient remobilization of apple leaves. New Phytol. 164:441-450.

Tewari, K.A. and C.B. Tripathy. 1998. Temperaturestress-induced impairment of chlorophyll biosynthetic reactions in cucumber and wheat. Plant Physiol. 117:851-858.

Teixeira, E.I., G. Fischer, H. van Velthuizen, C. Walter, and F. Ewert. 2013. Global hot-spots of heat stress on agricultural crops due to climate change. Agr. Meteorol. 170:206-215.

Werner, C., O. Correia, and W. Beyschlag. 2002. Characteristic patterns of chronic and dynamic photoinhibition of different functional groups in a Mediterranean ecosystem. Funct. Plant Biol. 29:999-1011.

Wünsche, J.N., J. Bowen, I. Ferguson, A. Woolf, and T. McGhie. 2004. Sunburn on apples causes and control mechanisms. Acta Hort. 636:631-636.

Yan, K., P. Chen, H. Shao, L. Zhang, and G. Xu. 2011. Effects of short-term high temperature on photosynthesis and photosystem II performance in sorghum. J. Agron. Crop Sci. 197: 400-408. 